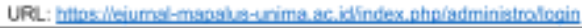

\title{
Pengaruh Profesionalitas Kerja Pegawai Terhadap Kualitas Pelayanan di Dinas Kependudukan dan Pencatatan Sipil Kabupaten Minahasa Selatan.
}

\author{
Cynthia Maria Siwi ${ }^{\text {a, } 1^{*}}$ \\ ${ }^{a}$ Universitas Terbuka Sulawesi Utara, Prodi Administrasi Negara, Manado, Indonesia \\ ${ }^{1}$ mariasiwi@ecampusut.ac.id *
}

Key word:

Employee work

professionalism, Service

Quality, Population and

Civil Registration Service

This study aims to determine and analyze the effect of employee work professionalism on service quality at the Department of Population and Civil Registration of South Minahasa Regency. The research method used is a descriptive research method with a quantitative approach. The population of this study is all people who come on the 3rd week of March 2021 at the Population Service and the South Minahasa Civil Registry, totaling 350 people. The results found are the influence of employee performance $(X)$ on service quality $(Y)$, obtained by $72.6 \%$. There is an influence between employee performance on service quality at the Department of Population and Civil Registration of South Minahasa Regency where t count $>$ t table, or $14.177>1.9$. The results of the analysis of the Research Hypothesis Test through the correlation test where the significance value generated by the employee's performance is 0.000, which means it is smaller than 0.05, this shows that the employee's performance has a linear influence on service quality. Employee performance also has a positive influence on service quality.

\section{INTISARI}

Kata kunci:

Profesionalitas Kerja

Pegawai,

Kualitas Pelayanan,

Pelayanan Kependudukan

dan Pencatatan Sipil
Penelitian ini bertujuan untuk mengetahui dan menganalisis pengaruh profesionalitas kerja pegawai terhadap kualitas pelayanan pada Dinas Kependudukan dan Catatan Sipil Kabupaten Minahasa Selatan. Metode penelitian yang digunakan adalah metode penelitian deskriptif dengan pendekatan kuantitatif. Populasi penelitian ini adalah seluruh masyarakat yang datang pada minggu ke 3 bulan Maret 2021 di Dinas Kependudukan dan Catatan Sipil Minahasa Selatan yang berjumlah 350 orang. Hasil yang ditemukan adalah pengaruh Profesionalitas Kerja karyawan (X) terhadap kualitas pelayanan (Y), diperoleh sebesar 72,6\%. Terdapat pengaruh antara Profesionalitas Kerja pegawai terhadap kualitas pelayanan pada Dinas Kependudukan dan Catatan Sipil Kabupaten Minahasa Selatan dimana t hitung > ttabel, atau 14,177 > 1,9. Hasil analisis Uji Hipotesis Penelitian melalui uji korelasi dimana nilai signifikansi yang dihasilkan oleh Profesionalitas Kerja karyawan adalah 0,000 yang artinya lebih kecil dari 0,05 hal ini menunjukkan bahwa Profesionalitas Kerja karyawan berpengaruh linier terhadap kualitas pelayanan. Profesionalitas Kerja pegawai juga berpengaruh positif terhadap kualitas pelayanan.

Copyright $\mathbb{C} 2021$ (Cythia Maria Siwi). All Right Reserved
1. Pendahuluan

* Korespondensi Penulis; e-mail: mariasiwi@ecampusut.ac.id
12

Sumber daya manusia (SDM) merupakan modal dasar pembangunan nasional, oleh karena itu 
maka kualitas sumber daya manusia senanntiasa sangat berperan penting dalam suksesnya organisi. Begituj banyak organisasi-organisasi yang ujnggujl dan saling bersaing membat strategi, sasaran, dan inovasi dalam mencapai apa yang menjadi tujuan. Oleh karenanya sumber daya manusia merupakan unsur vital dalam organisasi. Dalam Sumber Daya Manusia (SDM) ada dua hal yang sangat mempengaruhi efektivitas dan efisiensi organisasi dimana Sumber Daya Manusia merencanakan serta mengawasi kualitas, mengalokasikan Sumber Daya finansial, memasarkan produk bahkan menentukan srategi dalam mencapai tujuan organisasi. Kedua, Sumber Daya Manusia dalam organisasi merupakan pengeluaran utama dalam menjalankan sebuah bisnis. Berbicara soal Manajemen Sumber Daya Manusia tentunya memiliki hubungan dengan sistem didalam organisasi dalam menentukan efisiensi dan efektivitas dalam mewujudkan tujuan atau visi dan misi organisasi yang sudah ditetapkan sebelumnya

Terwujudnya pelayanan publik yang berkualitas merupakan salah satu ciri great administration sebagai tujuan pendayagunaan aparatur negara. Sehubungan dengan itu, sesuai dengan Undang-Undang Nomor 25 Tahun 2009 Tentang Pelayanan Publik merupakan suatu upaya yang harus dilakukan secara terus menerus, berkelanjutan dan harus dilaksanakan oleh semua para aparatur pemerintah [1]. Seiring berjalannya waktu pengelolaan sumber daya manusia akan menjadi bagian yang sangat penting dari tugas manajemen organisasi untuk menentukan kesuksesan organisasi di masa mendatang dan sebaliknya jika sumber daya manusia tidak dikelola dengan baik maka efektivitas tidak akan tercapai. Komplektivitas pengelolaan sumber daya manusia sangat dipengaruhi banyak faktor, hal ini sesuai dengan perkembangan dan kemajuan yang belangsung saatini.

Untuk mengatur tata pelaksanaan penyelenggaraan organisasi, perlu diciptakan pengaturan administrasi pemerintahan atau suatu mekanisme, sistematik yang menjamin terwujudnya fungsi-fungsi pemerintahan, yang lebih baik dan akurat dengan demikian Sumber Daya Manusia yang dimiliki suatu institusi dapat teratur dengan baik demi menggapai visi dan misi institusi tersebut. Aparat instansi pemerintah dan kualitas Sumber Daya Manusia sangat berperan dalam kemajuan tersebut, selain itu aparat pemerintahan dan instansi sumber daya manusia sebagai penopang atau pendorong peningkatan kualitas institusi menjadi lebihbaik.Tinggi rendahnya Sumber Daya Manusia dilihat dari Profesionalitas Kerja aparat pemerintah serta kualitas pelayanan dapat diukur sejauh mana aktifitas dan efisiensi dalam memberikan pelayanan kepada masyarakat.Faktor-faktor yang diperhitungkangairah kerja aparat pemerintah adalah kualitas kemampuan dan Profesionalitas
Kerja yang dimiliki seorang aparatur dalam melayani masyarakat.

Dinas Kependudukan dan Catatan Sipil Minahasa Selatan adalah badan/badan pelayanan umum di bidang kependudukan dan pencatatan sipil. Pencatatan kependudukan di Indonesia meliputi pembuatan Kartu Tanda Penduduk Elektronik atau dikenal dengan nama (e-KTP) kemudian pembuatan Kartu Keluarga (KK), Penghapusan Surat dan Kartu Tanda Penduduk (KIA), sedangkan pencatatan sipil meliputi pembuatan Akta Kelahiran, Kematian, Perceraian dan Pengakuan. persetujuan anak dan anak, pendaftaran perubahan nama, pendaftaran perubahan kewarganegaraan. Dengan visi "terwujudnya pengelolaan kependudukan yang tertib berbasis Sistem Informasi Manajemen Kependudukan (SIAK) melalui pelayanan prima" dan misi "tercapainya pelayanan prima kepada masyarakat di bidang Kependudukan dan Kedudukan Kependudukan Tercapainya pengelolaan yang mudah, cepat, akurat dan kondisi pelayanan yang transparan dalam kerangka pelayanan kependudukan dan status sipil untuk mencapai pelayanan prima.

Berdasarkan pengamatan penulis, Profesionalitas Kerja pegawai pemerintah daerah di register selatan Minahasa, khususnya di kantor kependudukan dan catatan sipil, tampak semakin kurang efisien dan efektif. Hal ini terlihat dari Profesionalitas Kerja setiap pegawai yang belum mencapai tingkat optimal dalam menjalankan tugas maupun fungsi telah dirumuskan dari pemerintah daerah. Dengan demikian menunjukkan bahwa Profesionalitas Kerja pegawai dipandang jauh dari harapan masyarakat terhadap kantor sehingga menyebabkan masalah serta isu yang tidak baik. Minimnya fasilitas dari pemerintah menjadi masalah bagi Dinas Kependudukan dan Statistik Vital Kabupaten Minahasa Selatan, dan pemantauan Profesionalitas Kerja staf memberikan kesan bahwa organisasi berfungsi dengan baik tanpa uji tuntas.prinsip desentralisasi dan sentralisasi. Berangkat dari permasalahan di atas, maka penulis tertarik dengan permasalahan ini perlu dikaji dan diperdalam dengan judul: "Pengaruh Profesionalitas Kerja Pegawai Terhadap Kualitas Pelayanan di Dinas Kependudukan dan Pencatatan Sipil Kabupaten Minahasa Selatan"

\section{Metode Penelitian}

Menurut Sugiyono, Metode penelitian kuantitatif dapat diartikan sebagai metode penelitian yang berlandaskan pada filsafat positivisme, digunakan untuk meneliti pada populasi atau sampel tertentu, teknik pengambilan sempel pada umumnya dilakukan secara random, pengumpulan data menggunakan instrumen penelitian, analisis data bersifat kuantitatif/statistik dengan tujuan untuk menguji hipotesis yang telah ditetapkan [2]. 
Metode yang dipakai dalam penelitian ini yaitu metode penelitian deskriptif kuantitatif. Dimana Penelitian Kuantitatif adalah penelitian yang ilmiah yang sistematis terhadap bagian-bagain dan fenomena serta hubungan- hubungannya.Ini karena fokus eksplorasi yang merasakan seberapa besar dampak eksekusi pekerja terhadap kualitas bantuan.Melalui strategi ini, sangat mungkin terlihat permasalahan terkonsentrasi pada setiap faktor, baik variabel $X$ (Variabel Independen) sebagai variabel otonom maupun variabel $\mathrm{Y}$ (Variabel Dependen) sebagai variabel dependen.

Dalam penelitian ini variabel yang akan diteliti adalah :

2.1 Variabel Bebas/Independent Variabel $(X)$ Adalah

Profesionalitas Kerja Pegawai,

Profesionalitas Kerja merupakan bagian fundamental dari sebuah instansi dalam rangka mendukung pencapaian sasaran dan tujuan institusi itu sendiri.Selanjutnya Profesionalitas Kerja menjadi organ dalam sebuah institusi yang mengorganisir pelaksanaan dan penyelesain segala hal yang sifatnya adninistratif.

Ada beberapa faktor yang berpengaruh terhadap Profesionalitas Kerja terkait dengan penelitian yang dilakukan seperti dikutip dari Harbani Pasolong yaitu:

a. Kemampuan

Adalah suatu kapasitas atau keahlian dari seseorang atau individu dalam melaksanakan segala tugas yang diberikan dalam suatu pekerjaan. Pada umumnya kemampuan erat kaitannya dengan bakat atau minat.

b. Kemauan

Bisa juga dikatakan sebagai keinginan atau sikap seseorang untuk melakukan sesuatu atau kesedian seseorang untuk melakukan sesuatu dalam mencapai tujuan organisasi..

c. Energi

Dalam hal ini energi diartikan sebagai semangat untuk melaksanakan tugas

d. Teknologi merupakan hal yang mendukung seseorang dalam melaksanakan tugas. Penerapan teknologi merupakan pengetahuan untuk melakukan pekjerjaan agar efektif dan efisien.

e. Kompensasi

Adalah suatu hak yang wajib di berikan dan diterima oleh pegawai atau karyawan sebagi bentuk balas jasa terhadap pekerjaan yang telah dilakukan dimana pegawai memperoleh kompensasi sesuai dengan Profesionalitas Kerjanya.

f. Kejelasan tujuan

Dalam mencapai Profesionalitas Kerja pegawai atau karyawan yang tinggi maka diperlukannya tujuan yang jelas berbanding terbalik apabila pegawai atau karyawan tidak mengetahui tujuan pekerjaan maka tidak tercapainya suatu efisiensi kerja dalam suatu organisasi.

g. Keamanan

Merupakan suatu hal yang mendasar dalam kebutuhan manusia terlebih lagi dalam melakukan pekerjaan dikarenakan dengan merasa aman atau keamanan terjamin lebih penting daripada kenaikan pangkat atau gaji oleh karen aitu dengan keamanan yang terjamin makan kinerjka yang tinggi dapat tercapai. [3].

\subsection{Variabel Terikat Atau Dependent Variabel (Y)}

Adalah Kualitas Pelayanan.

Agung Kurniawan mengatakan bahwa "pelayanan publik adalah pemberian pelayanan (melayani) keperluan orang lain atau masyarakat yang mempunyai kepentingan pada organisasi itu sesuai dengan aturan pokok dan tata cara yang telah ditetapkan". [4]. Indicator dalam penelitian ini di kutip dari Pasolong mengatakan bahwa kualitas pelayanan prima tercermin dari:

1) Transparansi

Pada dasarnya merupakan pelayanan yang sifatnya terbuka kepada umum atau publik, serta mudah diakses, mudah dimengerti oleh semua orang yang membutuhkan informasi.

2) Akuntabilitas,

Yaitu bentuk pertanggungjawaban dari pelayanan yang dilakukan yang berdasar pada peraturan yang berlaku.

3) Kondisional,

Merupakan pelayanan yang dilakukan sesuai dengan kemampuan dan kondisi pemberi layanan dan penerima layanan yang berpegang pada prinsip evektivitas dan efisiensi serta aturan yang ada.

4) Partisipatif,

Merupakan pelayanan yang mengikutsertakan partisipasi atau dukungan dari masyarakat dengan memperhatikan kebutuhan, harapan dan aspirasi masyarakat.

5) Kesamaan hak,

Merupakan pelayanan yang dilakukan dengan tidak memandang pada ras, suku, aagama, status sosial dan lain sebagainya.

6) Keseimbangan hak dan kewajiban,

Merupakan pelayanan dengan memperhatikan atau menimbang aspek keadilan yaitukesamaan hak antara pemberi layanan maupun penerima layanan [3].

Arikunto, Instrumen penelitian adalah alat atau fasilitas yang digunakan peneliti dalam mengumpulkan data agar pekerjannya lebih mudah dan hasilnya lebih baik, dalam arti lebih cermat, lengkap dan sistematis sehingga lebih mudah diolah. Variasi jenis instrumen penelitian adalah, 
angket, check list atau daftar centang, pedoman wawancara, pedoman pengamatan [5].

Adapun teknik pengumpulan data yang digunakandalam penelitian ini adalah:

1. teknik angket Penggunaan teknik ini dilakukan untuk mengetahui data tentang Pengaruh Profesionalitas Kerja pegawai terhadap kualitas pelayanan di Dinas Kependudukan dan Pencatatan Sipil Kabupaten Minahasa Selatan. Dengan angket ini diharapkan responden mudah memberikan jawaban karena alternatif Pengukuran pada variabel yang diungkap dilakukan dengan memberikan skor dari jawaban angket.

2. Wawancara yaitu memeperoleh data dengan cara mengamati dan memperleh pernyataan dari informan terkait hasil Profesionalitas Kerja pegawai melalui pelayanan yang dilakukan sebelum tahap pertama. [6].

Penelitian ini menggunakan skala likert Skala likert yaitu skala yang berisi pernyataan-pernyataan sikap (attitude statement). Pernyataan sikap adalah suatu pernyataan mengenai objek sikap yang menggunakan distribusi respons sebagai dasar penentuan nilai skalanya.Dalam skala likert ada dua pernyataan sikap, yaitu pernyataan yang bersifat mendukung/positif (favourable) dan pernyataan yang tidak mendukung/ negatif (unfavourable) Menurut Sugiyono, Pada angket penelitian ini semua pernyataan yang berjumlah 31 item bersifat favourable. Jawaban pada instrumen apa saja yang menggunakan skala likert yang memiliki gradasi dari sangat positif hingga sangat negative [2].

Instrumen Penelitian yang telah disusun harus diuji cobakan terlebih dahulu untuk mengetahui kelayakan instrument penelitian yang digunakan, maka itu dilakukan prosedur:

Uji Validitas Dalam penelitian ini Dasar Pengambilan Uji Validitas Pearson Pembandingkan nilai rhitung dengan rtabel

- $\quad$ Jika nilai rhitung $>$ rtabel $=$ valid

- $\quad$ Jika nilai rhitung $<$ rtabel $=$ tidak valid cara mencari nilai rtabel dengan jumlah responden / $\mathrm{n}=78$ pada signifikansi $5 \%$ pada distribusi nilai rtabel statistik.

Uji Reliabilitas pengambilan keputusan dalam uji reliabilitas adalah sebagai berikut:

- Jika nilai Cronbach's Alpha > 0,60 maka Kuesioner atau angket dinyatakan reliabel atau konsisten.

- $\quad$ Sementara, jika nilai Cronbach's Alpha < 0,60 maka kuesioner atau angket dinyatakan tidak reliabel atau tidak konsisten [2].

Populasi dalam penelitian ini adalah seluruh masyarakat yang datang pada minggu ke-3 bulan Maret tahun 2021 di Dinas Kependudukan dan Pencatatan Sipil Minahasa Selatan yang berjumlah 350 orang.

Penentuan ukuran sampel menggunakan pendapat dari Taro Yamane atau Slovin, yaitu dengan rumus :

$$
\mathrm{n}=\frac{N}{1+N \cdot \theta^{2}} \frac{N}{1+N \cdot \theta^{2}}
$$

Dimana

$\mathrm{n}$ : Jumlah Sampel

$\mathrm{N}$ : Jumlah Populasi

$\mathrm{e}^{2}$ : Kelonggaran ketidak telitian karena kesalahan pengambilan sampel yang dapat ditolelir (Umar, 2004).

Dari jumlah populasi tersebut dengan $(\mathrm{N})$ sebesar 350, tingkatkelonggaran (e) sebesar 10\% maka dengan menggunakan rumus di atas diperoleh sampel sebesar:

$\mathrm{n}=\frac{350}{1+350 \cdot(10 \%)^{2}} \frac{350}{1+350 \cdot(10 \%)^{2}}=77,78$ dibulatkan

menjadi 78 .

[2].

\section{Hasil dan Pembahasan (Times New Roman)}

\subsection{Hasil Penelitian}

Kabupaten Minahasa Selatan merupakan salah satu kabupaten di Provinsi Sulawesi Utara dengan ibu kota Amurang, Jarak dari Amurang ke Manado ibu kota Provinsi Sulawesi Utara $\pm 64 \mathrm{~km}$. Secara geografis, Kabupaten Minahasa Selatan terletak antara $0^{\circ}, 47^{\prime}-1^{\circ}, 24^{\prime}$ Lintang Utara dan $124^{\circ}, 18^{\prime}-124^{\circ} 45^{\prime}$ Bujur Timur. Sedangkan secara administratif terletak di sebelah Selatan Kabupaten Minahasa, dimana batas wilayahnya mencakup: Utara, berbatasan dengan Kabupaten Minahasa. Timur, berbatasan dengan Kabupaten Minahasa Tenggara.Selatan, berbatasan dengan Kabupaten Bolaang Mongondowdan Kabupaten Bolaang Mongondow Timur.Barat, berbatasan dengan Laut SulawesiLuas wilayah kabupaten Minahasa Selatan adalah berupa daratan seluas 1.484,47 km2.

Dinas Kependudukan dan Pencatatan Sipil mempunyai tugas dalam pelaksanaan urusan pemerintahan daerah dibidang administrasi kependudukan yang berdasar pada asas otonomi serta tugas pembantuan. Untuk melaksanakan tugas tersebut, Dinas Kependudukandan Pencatatan Sipil menyelenggarakan fungsi Penyusun program serta anggaran, fungsi pengelolaan perlengkapan dan keuangan, urusan rumah tangga dan barang milik Negara, urusan tata usaha, Penyusunan perencanaan di bidang pendaftaran penduduk, Pengelolaan urusan ASN, pengelolaan informasi administrasi kependudukan, pencatatan sipil, pemanfaatan data dan dokumen kependudukan serta inovasi pelayanan administrasi kependudukan, kerja sama administrasi kependudukan, Perumusan kebijakan teknis di bidang pendaftaran penduduk,pencatatan sipil, pengelolaan informasi administrasi kependudukan, kerja sama, pemanfaatan data dan dokumen kependudukan sertainovasi pelayanan administrasi kependudukan; Pelaksanaan pelayanan pendaftaran penduduk; Pelaksanaan pelayanan pencatatan sipil; Pelaksanaan pengelolaan informasi administrasi kependudukan; Pelaksanaan kerja sama 
administrasi kependudukan; Pelaksanaan pemanfaatan data dan dokumen kependudukan; Pelaksanaan inovasi pelayanan administrasi kependudukan; Pembinaan, koordinasi, pengendalian bidang administrasi kependudukan; Pelaksanaan kegiatan penatausahaan Dinas Kependudukan dan Pencatatan sipil; dan Pelaksanaan tugas lain yang diberikan oleh bupati/walikota sesuai dengan tugas dan fungsinya. Data dalam penelitian ini dengan menyebarkan kuisioner pada bulan febuari sampai dengan bulan april 2021, kemudiam peneliti mendeskripsikan tentang identitas responden dan analisis data kuantitatif dengan menggunakan pendekatan analisis data regresi sederhana, identitas responden ini meliputi, Nama, umur jenis kelamin, peneliti menggunakan alat bantu pengujian yaitu dengan Perangkat lunak (sofeware) SPSS (Statistical product and service solution) IBM, versi 25.0 for windows.

\subsubsection{Uji Validitas Profesionalitas Kerja Pegawai}

Hasil uji validitas Profesionalitas Kerja Pegawai, menunjukan bahwa nilai $\mathbf{r}_{\text {hitung }}$ dari setiap item pertanyaan satu sampai dengan pertanyaan sebelas, nilai $\mathbf{r}_{\text {hitung }}$ lebih besar dari $\mathbf{r}$ tabel, Maka dapat disimpulkan bahwa setiap butir pertanyaan dari variabel (X) Kineja Pegawaidinyatakan Valid.

3.1.2 Uji Validitas Kualitas Pegawai

Hasil uji validitas Kualitas Pelayanan, menunjukan bahwa nilai $\mathbf{r}_{\text {hitung }}$ dari setiap item pertanyaan satu sampai dengan pertanyaan sebelas, nilai $\mathbf{r}_{\text {nitung }}$ lebih besar dari $\mathbf{r}_{\text {tabel }}$, Maka dapat disimpulkan bahwa setiap butir pertanyaan dari variabel (Y) Kualitas Pelayanandinyatakan Valid.

3.1.3 Uji Realibilitas Profesionalitas Kerja Pegawai

Koefisien reliabilitas instrument Profesionalitas Kerja pegawai, nilai variabel tersebut menunjukkan bahwa koefisien Cronbach Alpha >0,6, yakni sebesar 0,903, sehingga dapat disimpulkan bahwa Variabel (X) Profesionalitas Kerja Pegawai dalam penelitian ini adalah reliabel.

\subsubsection{Uji Reabilitas Kualitas Pelayanan}

Koefisienreliabilitas instrument

Kualitas Pelayanan, nilai variabel tersebut menunjukkan bahwa koefisien Cronbach Alpha $>0,6$, yakni sebesar 0,876, sehingga dapat disimpulkan bahwa Kualitas Pelayanandalam penelitian ini adalah reliabel.

3.1.5 Uji Normalitas

Uji normalitas dilakukan untuk membuktikan bahwa skor-skor yang diperoleh dari setiap variabel dapat tersebar secara normal sehingga dapat digeneralisasikan pada populasi.Pada penelitian ini, pengukur teknik one-sample Kolmogorov Smirnov.Dalam SPSS
25 Asymp.Signifikan disimbolkan sebagai p. maka data dikatakan tersebar secara normal apabila $\mathrm{p}>0.05$, sedangkan jika $\mathrm{p}<0.05$ maka data tidak terdistribusi secara normal (Widhiarso, 2012).

Hasil Uji Normalitas data dengan menggunakan aplikasi SPSS versi 25 , dengan melihat tabel di atas, terlihat bahwa uji normalitas terhadap variabel Profesionalitas Kerja Pegawai dan Kualitas pelayanan menunjukkan nilai (Asymp. Signifikan) $/ \mathrm{p}=$ $0.112>0.05$, sehingga dapat disimpulkan bahwa data dari variabel Profesionalitas Kerja pegawai dan data dari variable kualitas pelayanan terdistribusi secara normal.

3.1.6 Uji Linearitas

Uji linearitas merupakan uji untuk melihat apakah ada hubungan linear yang signifikan dari variabel yang sedang diteliti.Kaidah yang digunakan jika nilai signifikan $\mathrm{p}<0.05$ maka ada hubungan linear yang signifikan dan sebaliknya, apabila nilai $\mathrm{p}$ $>0.05$ maka hubungan antara variabel bebas dan variabel tergantung dikatakan tidak linear.Uji linearitas dilakukan dengan menggunakan teknik uji $\mathrm{F}$ melalui bantuan program SPSS versi 25.

Berdasarkan hasil pengujian, nilai yang di peroleh sig adalah 0,948 yang berarti bahwa nilai signifikan pada linearity adalah $0,948>0,05$ maka didapat bahwa variabel Profesionalitas Kerja Pegawai dengan variabel Kualitas Pelayanan mempunyai hubungan linear.

\subsubsection{Uji Regresi Sederhana}

Hasil Utama Penelitian Penelitian ini bertujuan untuk mengetahui pengaruh Profesionalitas Kerja pegawai terhadap kualitas pelayanan.Pengujian ini dilakukan dengan menggunakan metode analisa regresi sederhana dengan bantuan aplikasi SPSS versi 25.Analisis regresi linear sederhana digunakan untuk menguji pengaruh satu variabel bebas terhadap variabel terkait.Tujuan dari analisis regresi linear sederana digunakan untuk menguji pengaruh satu variabel bebas terhadap variabel terikat. Adapun syarat uji regresi linear sederhana adalah data harus valid dan reliabel serta normal dan linear.Dalam hal ini data dari penelitian ini telah diuji dan dinyatakan valid dan reliabel serta normal dan linear. Dasar dari pengambilan keputusan ini mengacu pada dua hal, yakni:

Dasar dari pengambilan keputusan ini mengacu pada dua hal, yakni:

1. Jika nilai signifikansi $<0,05$ artinya variabel $\mathrm{X}$ berpengaruh terhadap variabel Y.

2. Jika nilai signifikansi $>0,05$, artinya variabel $\mathrm{X}$ tidak berpengaruh terhadap variabel Y.

Coefficients di atas di ketahui nilai 
constant (a) sebesar 14.799, sedangkan nilai Profesionalitas Kerja pegawai (b) koefisien regresi sebesar 0.745 sehingga persamaan regresi dapat di tulis:

\section{$Y=14.799+0.745 X$}

a. Persamaan tersebut dapat di terjemahkan: 1) Konstanta sebesar 14.799, mengandung arti bahwa nilai konsisten variabel Kepuasan Pasien adalah sebesar 14.799 .

2) Koefisien regresi $X$ sebesar 0.745 menyatakan bahwa setiap pertambahan $1 \%$ nilai Profesionalitas Kerja Pegawai, maka nilai Kualitas pelayanan bertambah sebesar 0 . 277.Koefisien regresi tersebut bernilai positif, sehingga dapat di katakana bahwa arah pengaruh Variabel $\mathrm{X}$ terhadap $\mathrm{Y}$ adalah positif

b. Pengambilan keputusan dalam uji regresi sederhana.

Berdasarkan nilai signifikansi dari tabel coefficients di atas di peroleh nilai signifikansi sebesar $0.001<0.005$, sehingga dapat di simpulkan bahwa variabel Profesionalitas Kerja pegawai (X) berpengaruh terhadap variabel Kualitas pelayanan $(\mathrm{Y})$.

\subsubsection{Koefisien Determinasi}

Koefisien korelasi kuadrat (r2) disebut koefisien determinasi atau koefisien determinasi.Koefisien determinasi adalah proporsi untuk menentukan besarnya persentase pengaruh antara variabel $\mathrm{X}$ dan variabel Y bila dikalikan $100 \%$.

Dalam hal ini peneliti menggunakan analisis data SPSS 25, diperoleh nilai R Square atau koefisien kepastian (KD) yang menunjukkan seberapa besar model kekambuhan yang dibingkai oleh asosiasi variabel otonom dan variabel terikat. Nilai $\mathrm{R}$ Square yang didapat adalah 0,726 yang kemudian dinaikkan 100\% sehingga diperoleh nilai R Square sebesar $72,6 \%$ yang dapat diartikan bahwa faktor bebas/X (Profesionalitas Kerja Karyawan) memiliki dampak komitmen sebesar 72,6\% terhadap variabel terikat/Y (Kualitas pelayanan). 3.1.9 Uji t

Berdasarkan perhitungan, $\alpha \alpha=0,05$ dan $\mathrm{n}=78$, diperoleh $\mathrm{t}_{\text {hitung }}=14,177$ sedangkan $\mathrm{t}_{\text {tabel }}$ pada $\alpha=0,05 \alpha=0,05$ dengan $\mathrm{n}=78$ diperoleh $\mathrm{t}_{\text {tabel }}=1,9$. Ternyata $\mathrm{t}$ hitung lebih besar dari t tabel.Dasar untuk membandingkan nilai Thitung dengan Ttabel adalah dimana jika nilai Thitung $>$ Ttabel artinya variabel $\mathrm{X}$ berpengaruh terhadap variabel $Y$. dan sebaliknya, jika nilai Thitung $<$ Ttabel artinya variabel X tidak berpengaruh terhadap variabel Y.

Maka terdapat pengaruh yang signifikan antara Profesionalitas Kerja pegawai terhadap kualitas pelayanan di dinas kependudukan dan pencatatan sipil kabupaten minahasa selatan, dimana $\mathrm{t}$ hitung $>\mathrm{t}$ tabel, atau $14,177>1,9$. Dengan demikian Ho diterima dan Ha ditolak.

\subsubsection{Uji Hipotesis \\ Pengujian hipotesis penelitian adalah} suatu prosedur yang menghasilkan suatu keputusan menerima atau menolak hipotesis tersebut.Hipotesis untuk analisis korelasi dirumuskan dalam bentuk hipotesis penelitian dan hipotesis statistik.

Dari hasil perhitungan yang dilakukan melalui aplikasi SPSS versi 25 dihasilkan nilai signifikan 0,000 , dimana nilai signifikan $<0,05$ atau $0,000<0,05$ artinya Profesionalitas Kerja Pegawai mempengaruhi Kualitas Pelayanan pada Dinas Kependudukan dan pencatatan Sipil Kabupaten Minahasa Selatan. Hasil analisis membuktikan bahwa Hipotesis atau $\mathrm{H}_{\mathrm{o}}$ dalam penelitian ini diterima.

\subsection{Pembahasan}

Penelitian Untuk menguji dan memberikan hipotesa yang telah diajukan dapat digunakan statistic uji Correlational Products Moment untuk hipotesis analisis $\mathrm{X}$ terhadap $\mathrm{Y}$ atau Pengaruh Profesionalitas Kerja pegawai terhadap Kualitas pelayanan.

Berdasarkan hasil pengolahan dan analisis pengujian regersi sederhana pengaruh Profesionalitas Kerja pegawai (X) terhadap kualitas pelayanan (Y), maka diperoleh $r$ square $=0,726$ yang kemudian dikalikan 100\% maka diperoleh nilai $\mathrm{r}$ square sebesar 72,6\%. Maka terdapat pengaruh antara Profesionalitas Kerja pegawai terhadap kualitas pelayanan di Dinas Kependudukan dan Pencatatan Sipil Kabupaten Minahasa Selatan, dimana $\mathrm{t}$ hitung $>\mathrm{t}$ table, atau $5,416>1,886$. Dengan demikian Ho diterima dan Ha ditolak.

Hasil analisis Uji Hipotesis Penelitian melalui uji regersi sederhana dimana nilai signifikansi yang dihasilkan Profesionalitas Kerja pegawai adalah 0,000 yang artinya lebih kecil dari 0,05 hal ini menunjukan bahwa kineja pegawai mempengaruhi secara linear kepada kualitas pelayanan. Profesionalitas Kerja pegawai juga memiliki pengaruh yang positif terhadap kualitas pelayanan, sehingga hasil analisis membuktikan bahwa Hipotesis atau $\mathrm{H}_{\mathrm{o}}$ dalam penelitian ini diterima.

Profesionalitas Kerja merupakan bagian bagian fundamental dari sebuah instansi dalam rangka mendukung pencapaian sasaran dan tujuan institusi itu sendiri.Selanjutnya Profesionalitas Kerja menjadi organ dalam sebuah instirtusi yang 
mengorganisirpelaksanaan dan penyelesaian segala hal yang sifatnya administrative.Eksekusi adalah bagian utama dari sebuah organisasi untuk membantu pencapaian tujuan dan sasaran yayasan yang sebenarnya. Selain itu, eksekusi menjadi organ dalam suatu lembaga yang mengatur pelaksanaan dan pelaksanaan setiap urusan kekuasaan. [7]. Sinambela, mendefinisikan "Profesionalitas Kerja pegawai sebagai kemampuan pegawai dalam melakukan sesuatu dengan keahlian tertentu".Profesionalitas Kerja merupakan bagian fundamental dari sebuah instansi dalam rangka mendukung pencapaian tujuan dan sasaran institusi itu sendiri. Selanjutnya Profesionalitas Kerja menjadi organ dalam sebuah institusi yang mengorganisir pelaksanaan dan penyelesain segala hal yang sifatnya adninistratif [8]. Dalam proses mencapai suatu tujuan atau sasaran dalam organisasi maka dibagi atau dibentuk dalam unit-unit kerja atau bidang-bidang dengan pembagian kerja yang jelas. Rivai menyatakan bahwa Profesionalitas Kerja merupakan prilaku yang nyata yang ditampilakan setiap orang sebagai prestasi kerja yang dihasikan oleh karyawan yang sesuai dengan perananya pada sebuah instansi.Profesionalitas Kerja sebagai sumbangan kualitatif dan kuntitatif yang terukur dalm rangka membatu tercapainya tujuan dalam unit kerja. Dari pengertian yang dikemukakan diatas dapat disimpulkan atau dijelaskan bahwa Profesionalitas Kerja pegawai merupakan kemampuan atau keahlian dalam melakukan pekerjaan dalam pencapaian tujuan organisasi. Profesionalitas Kerja merupakan bagian fundamental dari sebuah instansi dalam proses mencapai suatu tujuan atau sasaran dalam organisasi maka dibagi atau dibentuk dalam unit-unit kerja atau bidang-bidang dengan pembagian kerja yang jelas.[9].

Pasolong Kualitas pada dasarnya merupakan kata yang menyandang arti relatif bersifat abstrak, kualitas dapat digunakan untuk menilai atau menentukan tingkat penyesuaian suatu hal terhadap persyaratan atau spesifikasinya, 'Pelayanan berkualitas atau pelayanan prima yang berorientasi pada pelanggan sangat tergantung pada kepuasan pelanggan dan salah salah satu ukuran keberhasilan menyajikan pelayanan yang berkualitas (prima) [4].

Menurut Ibrahim Kualitas pelayanan merupakan suatu kondisi dinasmis yang berhubungan dengan produk, jasa, manusia, proses, dan lingkungan dimana penilaian kualitasnya ditentukan pada saat terjadinya pemberian pelayanan public tersebut.Berkaitan dengan pelayanan publik secara umum, ada dua istilah yang perlu diketahui, yaitu melayani dan pelayanan. Pengertian melayani adalah membantu menyiapkan dan mengurus apa yang dipelukan seseorang [10]. Hal ini sejalan dengan pemikir gronroos dalam Pasolong yang menyatakan bahwa pelayannan adalah suatu aktivitas yang bersifat tidak kasat mata sebagai akibat adanya interaksi antara konsumen dan pegawai [4].

Pengertian mengenai kualitas pelayanan public dikemukakan pula oleh Yamit yang menjelaskan bahwa kualitas pelayanan sebagai perbandingan antara harapan konsumen dengan Profesionalitas Kerja kualitas jasa pelayanan. Definisi lain mengenai kualitas pelayanan diberikan oleh Lewis dan Booms yang mendefinisikan kualitas pelayanan sebagai ukuran seberapa bagus tingkat layanan yang diberikan mampu sesuai dengan ekspektasi pelanggan. Mengacu pada definisi tersebut, Tjiptono menambahkan pula bahwa kualitas pelayanan dapat diwujudkan melalui pemenuhan kebutuhan dan keinginan pelanggan serta ketepatan penyampaianya untuk mengimbangi harapan pelanggan. Dengan demikian kualitas pelayanan dipengaruhi oleh dua factor yaitu customer expectation (harapan pelanggan) dan customer perceived (yang dirasakan pelanggan) atas suatu pelayanan. Lebih lanjut Tjiptono menjelaskan bahwa expectation merupakan tingkat Profesionalitas Kerja pelayanan yang seharusnya didapatkan atau diharapkan dari suatu pelayanan sedangkan perceived merupakan penilaian terhadap Profesionalitas Kerja pelayanan berdasarkan apa yang di rasakan dari awal proses pelayanan sampai diterimanya produk pelayanan [11]

Menurut William Dunn , tahap-tahap kebijakan publik adalah: Tahap Penyusuan Agenda, Formulasi Kebijakan, Adopsi Kebijakan, Implementasi Kebijakan, dan Evaluasi Kebijakan. Kebijakan publik dipengaruhi oleh tiga lingkungan yaitu lingkungan formulasi, lingkungan implementasi, dan lingkungan evaluasi. Analisis implementasi yang mempengaruhi lingkungan implementasi adalah actor, struktur organisasi dan jaringan komunikasi atau kepatuhan [12].

Implementasi kebijakan berkenaan dengan pelaksanaan kebijakan yang telah ditetapkan dan berbagai upaya dalam bentuk kegiatan yang diarahkan untuk merealisasikan kebijakan melalui program-program tertentu.Langkai membahas tentang model-model implementasi kebijakan:Model Van Meter dan Van Horn, Model Mazmanian dan Sabatier, Model George C. Edward III, Model Grindle, Model Elmore, Model Nakamura dan Smallwod.

Langkai membahas bahwa Model ini mengembangkan model implementasi yang menekankan keberhasilan implementasi kebijakan dikendalikan oleh ketepatan perincian strategi yang tidak menimbulkan perbedaan pemahaman oleh majelis yang bersangkutan, ketersediaan majelis untuk melaksanakan penataan sebagai Digambarkan dalam pendekatan terakhir penilaian strategi dalam hal pencapaian dan keuntungan yang dihasilkan dan kemungkinan membuat pertemuan lain yang merugikan. Strategi publik dipengaruhi oleh tiga kondisi, yaitu iklim perincian, iklim pelaksanaan, dan iklim penilaian. Investigasi eksekusi yang 
mempengaruhi iklim eksekusi adalah penghibur, desain hierarkis dan organisasi atau konsistensi korespondensi [13]

Suatu pelayanan dapat dikatakan berkualitas jika pelayanan yang dilakukan dapat menjawab dan memenuhi informasi atau kebutuhan serta harapan-harapan masyarakat, sebaliknya jika masyarakat tidak merasa puas dari pelayanan yang diberikan maka pelayanan tersebut merupakan suatu kegagalan dalam suatu pelayanan atau bisa dikatakan tidak berkualitas oleh karena itu dalam melakukan pelayanan kualitas dari pelayanan itu sendiri harus ditingkatkan dan selalu terfokus pada tingklat kepuasan penerima layanan atau pelanggan.

Menurut Moenir Pelayanan publik adalah kegiatan yang dilakukan oleh seseorang atau sekelompok orang dengan landasan faktor material melalui sistem, prosedur dan metode tertentu dalam usaha memenuhi kepentingan orang lain sesuai dengan haknya. Tujuan pelayanan publik adalah mempersiapkan pelayanan publik tersebut yang dikehendaki atau dibutuhkan oleh publik, dan bagaimana menyatakan dengan tepat kepada publik mengenai pilihannya dan cara mengaksesnya yang direnecanakan dan disediakan oleh pemerintah [14].

Menurut Moenir mengemukakan bahwa "pelayanan adalah suatu proses pemenuhan kebutuhan melalui aktivitas orang lain yang berlangsung". Dalam buku yang sama di kemukakan sebagai berikut pelayanan pada hakikatnya adalah serangkain kegiatan karena itu merupakan proses pelayanan berlangsung secara rutin dan kesinambungan meliputi seluruh kehidupan orang dalam masyarakat, kebutuhan manusia akan layanan dapat digambarkan melalui teori Life Cycle of leadership(LCTL [15].

Pelayanan menurut Yandianto adalah perihal atau cara melayan, service jasa dan kemudahan yang diberikan sehubungan dengan jual beli barang atau jasa [16]. Selanjutnya, pelayanan publik menurut Kurniawan adalah pemberian pelayanan (melayani) keperluan orang atau masyarakat yang mempunyai kepentingan pada organisasi itu sesuai dengan aturan pokok dan tata cara yang ditetapkan" [16]. Berdasarkan Ketetapan Menteri Perdayagunaan Aparatur Negara No. 63/KEP/M.PAN/7/2003 dalam Sinambela bahwa pelayanan publik adalah "Segala kegiatan pelayanan yang dilaksanakan oleh penyelenggara pelayanan publik sebagai upaya pemenuhan kebutuhan penerima layanan, maupun dalam rangka pelaksanaan ketentuan peraturan perundang-undangan [16]. Sesuai dengan Undang-Undang Republik Indonesia No. 25 tahun 2009 pasal 1 ayat (1) tentang pelayanan publik disebutkan bahwa "Pelayanan publikadalah kegiatan atau rangkaian kegiatan dalam rangka pemenuhan kebutuhan pelayanan sesuai dengan peraturan perundang-undangan bagi setiap warga negara dan penduduk atas barang jasa, dan pelayanan administratif yang disediakan oleh penyelenggara pelayanan public [16].

Untuk mengatur tata pelaksanaan penyelenggaraan organisasi, perlu diciptakan pengaturan administrasi pemerintahan atau suatu mekanisme, sistematik yang menjamin terwujudnya fungsi-fungsi pemerintahan, yang lebih baik dan akurat dengan demikian Sumber Daya Manusia yang dimiliki suatu institusi dapat teratur dengan baik demi menggapai visi dan misi institusi tersebut. Komplektivitas pengelolaan sumber daya manusia sangat dipengaruhi banyak faktor, hal ini sesuai dengan perkembangan dan kemajuan yang belangsung saatini.Aparat instansi pemerintah dan kualitas Sumber Daya Manusia sangat berperan dalam kemajuan tersebut, selain itu aparat pemerintahan dan instansi sumber daya manusia sebagai penopang atau pendorong peningkatan kualitas institusi menjadi lebihbaik.Tinggi rendahnya Sumber Daya Manusia dilihat dari Profesionalitas Kerja aparat pemerintah serta kualitas pelayanan dapat diukur sejauh mana aktifitas dan efisiensi dalam memberikan pelayanan kepada masyarakat.Faktor-faktor yang diperhitungkangairah kerja aparat pemerintah adalah kualitas kemampuan dan Profesionalitas Kerja yang dimiliki seorang aparatur dalam melayani masyarakat.Kualitas administrasi dapat dicirikan sebagai seberapa jauh kontras antara dunia nyata dan asumsi klien untuk administrasi yang mereka dapatkan/dapatkan.Bantuan besar seringkali diputuskan oleh pembeli langsung dari perwakilan sebagai individu yang melayani atau juga disebut sebagai pembuat administrasi, oleh karena itu upaya diharapkan dapat meningkatkan sifat kerangka bantuan yang diberikan untuk memuaskan keinginan dan meningkatkan loyalitas konsumen. Administrasi yang berkualitas adalah administrasi yang dapat memberikan pemenuhan kepada klien dan tetap berada dalam batasan pedoman bantuan yang memuaskan yang dapat diwakili dan harus dilakukan secara konsisten.

Berdasarkan Uraian Diatas Peneliti sejalan dengan penelitian yang dilakukan oleh [7], mengenai Pengaruh Profesionalitas Kerja Pegawai Terhadap Kualitas Pelayanan Pada Dinas Kependudukan Dan Pencatatan Sipil Kabupaten Minahasa"hasil penelitian nya menunjukan. Profesionalitas Kerja pegawai berpengaruh positif dan sangat signifikan terhadap kualitas pelayanan publik. Kedua variabel mempunyai hubungan fungsional yang berpola linear dan bersifat kontribusif. Apabila pelayanan publik ditingkatkan kualitasnya, maka akan mendorong peningkatan Profesionalitas Kerja pegawai, khususnya pada Dinas Kependudukan dan Pencattan Sipil Kabupaten Minahasa. Namun demikian masih ada dimensi kualitas pelayanan belum dicapai secara optimal yakni dimensi empati.

\section{Kesimpulan}


Dengan adanya pengaruh Profesionalitas Kerja pegawai (X) yang ada di Dinas Kependudukan dan Pencatatan Sipil Kabupaten Minahasa Selatan, maka hal tersebut bisa menuntun untuk terjadinya peningkatan kualitas pelayanan (Y) di Dinas Kependudukan dan Pencatatan Sipil Kabupaten Minahasa Selatan menjadi lebih baik.

Berdasarkan hasil analisis data dan pembahasan maka dapat ditarik disimpulkan bahwa:

1. Hasil analisis regresi menunjukan $\mathrm{Y}=14.799+$ 0.745X, ini berarti jika Profesionalitas Kerja pegawai meningkat satu-satuan maka kualitas pelayanan di dinas kependudukan dan catatan sipil juga akan meningkat.

2. Kontribusi Pengaruh variable $X$ Profesionalitas Kerja pegawai terhadap variabel Y kualitas pelayanan sebesar 72, $6 \%$ dan sisamya $27,4 \%$ di tentukan oleh variabel lain yang tidak di teliti dalam penelitian ini.

Berdasarkan hasil uji $\mathrm{t}$ : diketahui nilai $\mathrm{t}_{\text {hitung }}$ sebesar $5.416>t_{\text {tabel }} 1,665$, sehingga dapat di simpulkan bahwa variabel Profesionalitas Kerja pegawai $(\mathrm{X})$ berperngaruh terhadap variabel Kualitas pelayan $(\mathrm{Y})$.

\section{Referensi}

[1] Undang Undang Nomor 25 Tahun 2009 tentang Pelayanan Publik. .

[2] Sugiyono, "Metode Penelitian Kuantitatif, Kualitatif dan R \& D.Bandung:Alfabeta.," Metod. Penelit. Kuantitatif, Kualitatif dan R D.BandungAlfabeta., 2012.

[3] Pasolong, Teori Administrasi Publik, Yogyakarta: Alfabeta, 2012.

[4] Pasolong, Teori Administrasi Publik, Bandung: Alfabeta, 2010.

[5] S. Arikunto, Prosedur Penelitian Suatu Pendekatan Praktik. Jakarta: Rineka Cipta., 2010.

[6] G. H. Tumbel and A. S. Langkay, "Pengaruh Budaya Organisasi Terhadap Akuntabilitas Kepala Sekolah," J. Kaji. Kebijak. dan Ilmu Adm. Negara (JURNAL Adm., vol. 1, no. 1, 2019.

[7] F. J. W. Wowor, "PENGARUH PROFESIONALITAS KERJA PEGAWAI TERHADAP KUALITAS PELAYANAN PADA DINAS KEPENDUDUKAN DAN PENCATATAN SIPIL KABUPATEN MINAHASA.," J. Adminsitarsi Unsrat, vol. 53, no. 9, pp. 1689-1699, 2019.

[8] L. P. Sinambela, Reformasi Pelayanan Publik:Teori, Kebijakan, dan. Implementasi. Jakarta: PT. BumiAksara., 2006.

[9] Rivai, Veithzal, Manajemen Sumber Daya Manusia untuk Perusahaan: dari Teori Ke Praktik, Edisi Pert. Jakarta: PT. Raja Grafindo Persada,., 2006.

[10] Hardiansyah, "Kualitas Pelayanan Publik Konsep Dimensi Indikator dan
Implementasinya," Gava Media, 2018.

[11] Yamit. Zulian., Manajemen Kualitas Produk dan Jasa. Yogyakarta: Ekonesia., 2004.

[12] G. H. Tumbel, "Kebijakan Pembangunan Berbasisi Lingkungan di Kota Manado," $J$. Kaji. Kebijak. dan iImu Adm. Negara, 2020.

[13] J. E. Langkay, Kebijakan Publik. Malang: CV Seribu Bintang, 2020.

[14] A. Moenir, Manajemen Pelayanan Umum Di Indonesia. Jakarta: , Bumi Aksara, 2001.

[15] A. Moenir, Manajemen Pelayanan Publik. Jakarta: Bina Aksara, 2000.

[16] M. Marthinus, "Optimalisasi Pelayanan Publik Di Kantor Kecamatan Suluun Tareran Kabupaten Minahasa Selatan Optimization," Optim. Pelayanan Publik Di Kant. Kec. Suluun Tareran Kabupaten Minahasa Selatan Optim., vol. 5, no. 1, pp. 122-136, 2020. 